\title{
Influence of Electronic Administration on Public Service Delivery among State Agencies in Kenya
}

\author{
Kenneth Goga Riany
}

\section{ABSTRACT}

\begin{abstract}
E-Administration remains a key E-Government strategy that seeks to ensure the management of the government institutions and organizations if effectively done to enhance effectiveness and proper service delivery. The purpose of this study was to examine the influence of E-Administration on the public service delivery among state agencies in Kenya. The study adopted a descriptive research design to collect data from the target population comprising of 4230 employees within the management cadre at 132 specific government state agencies. Convenient sampling technique was used by the study to sample the respondents within the 132 specific government state agencies. A sampling formula was applied to calculate the sample size of 365 employees and self-developed questionnaires were used to collect data from the sample. Data was analyzed using descriptive and inferential statistics. The study found that E-Administration had a significant and positive influence on public service delivery by the state agencies in Kenya. The study further established that strategy execution had a significant moderating effect on the relationship between E-Administration and public service delivery by the state agencies in Kenya. The study recommended that the government through the state agencies should embrace E-Administration as a way of enhancing public service delivery. The management of state agencies should furthermore embrace strategy execution practices so as to enable success of E-Administration.
\end{abstract}

Keywords: Electronic Administration, E-Government Strategies, Strategy Execution, Public service delivery and State agencies.

\section{INTRODUCTION}

In the modern World where technology is becoming the order of the day, organizations in both public and private sector are focusing on strategic management as a way of steering their effectiveness and performance. Technology is also getting into strategy and one of the major aspects of strategies in the $21^{\text {st }}$ century world is the electronic based administration or simply put - Electronic administration. It is the use of ICT to improve administrative processes and the internal working of departments within an organization [1].

Electronic administration has also been widely known as E-Management, is the use of ICT to improve administrative processes and the internal working of departments within an organization [1]. [2] states that while E-Services focus on so called "front-office" relations, E-Administration refers to the so called "back-office" organizational systems. EGovernment strategies within this domain deal with improving management from streamlining internal processes, cross-departmental flow of information and include initiatives such as E-Mail, Integrated human resources and payroll systems, Integrated financial management systems, web-based collaborative data resources platforms, electronic filing systems, electronic document management (EDMS), ERecruitment as well as enterprise resource planning [3].
Submitted : January 27, 2021

Published : March 16, 2021

ISSN: 2507-1076

DOI: $10.24018 /$ ejbmr.2021.6.2.712

Riany K. G.*

Jomo Kenyatta University of Agriculture and Technology, Nairobi, Kenya. (e-mail: rianyken@ gmail.com)
E-Administration is the use of ICT to improve administrative processes and the internal working of an organization's departments. It is based on various types of management work, internal routines, computerizing administrative jobs and realizing strategic connections among departments [4]. Globally E-Administration is changing the service delivery by reducing knowledge, increasing information access and control makes administration more informed, in a better position to understand and exercise its rights and E-Administration [5].

According to [6], given its back-office capability EAdministration is usually recognized as a precondition for developing E-Services and E-Democracy and to have well working E-Services, E-Administration is vital for the effective use and transfer of information, data and electronic records between various public institutions as it refers to the incorporation of ICT in public administrations from two perspectives: intra-office and inter-office. [7] states that EAdministration stands on the administrative modernization issue, on efficiency and efficacy of services and whether electronic services do or do not improve services to citizens.

Government performance is measured through service delivery and is therefore an essential function in the relationship between government and citizens [23] In the 21st century, the growing demand for accountability and efficient 
governance and provision of services have put under pressure on governments and public sector to deliver not only quality, but efficient and effective services [24]. Africa in particular, governments are trying to tackle the demand for efficient governance by re-engineering the processes of how government services are delivered to people. In this regard, E-Government has played, and is still playing a major role in developing and delivering services to citizens using online platforms that are faster and efficient. According to a 2014 Kenyan Public Service Commission evaluation report on the Public Service Compliance with Values and Principles in Articles 10 and 232 of the Constitution evaluation findings show that the public service, is making much effort at increasing the uptake of E-Administration in service delivery.

\section{A. Statement of the Problem}

The Government of Kenya enacted the Kenya EAdministration as one of the strategies of E-Government in 2004 [8]. It was introduced to tackle public service delivery challenges, has since gained growth which is vital in facilitating economic development and the government continues to give utmost consideration thereto. Despite its efforts, Kenya is currently ranked number 119 globally, retaining same ranking since 2012. Focusing on the African countries ranking, Kenya declined from position 7 in 2012 [27] to number 9 in 2014 [28]. According to E-Government Development Index Kenya was ranked second in East Africa after Rwanda [29]. Reports indicate that most government entities with E-Government strategies are not utilizing EGovernment in most of their transactions [20]. Not to mention E-Government in developing countries fail to meet many of their expected objectives and outcomes and, in some instances, fail to get off the ground entirely [15, 19, 21].

E-Administration in the African countries face many difficulties and there is need for more home-grown studies to bridge the existing knowledge gaps. The purpose of this study therefore to fill this gap by assessing the influence of EAdministration on the public service delivery in Kenya.

\section{B. Research Objectives}

i. To determine the influence of E-Administration on public service delivery among state agencies in Kenya.

ii. To investigate the moderating effect of strategy execution on the relationship between E-Administration and public service delivery of state agencies in Kenya.

\section{LITERATURE REVIEW}

\section{A. Technology Diffusion Theory}

The theory positions that it is easier to implement innovations that show an improved advantage over that which is to be replaced, making it easier to adopt [1]. The theory provides a vital view on one of the most challenging topics within the innovation field, namely, technology assessment, improvement, adoption, and implementation thus has become a common reference theory for empirical studies of technological strategies as its strength lies in its utility [12].

\section{B. Dynamic Capability Theory}

Dynamic capability theory, whose proponents [27] define as the organization's ability to purposely establish, reconfigure, create, and assimilate internal and external capabilities as well as resources with the goal of improving performance, service delivery and address the fast-changing business environment [13].

\section{Empirical Review}

[14] assessed the impact of the moderating role of EAdministration on training, performance appraisal and organizational performance. The study population comprised of employees working in twenty-five (25) companies where E-Administration was in place. Based on probability/simple random design, 245 employees were sampled, 220 employees responded to a structured questionnaire giving a response rate of $81 \%$. The study revealed the significance of EAdministration as a strategic element in improving organizational performance. E-Administration moderates the relation between performance appraisal and organizational performance as it plays a vital role in appraising the job performance of employees in transparent manner, it reduces the chances of bias and other errors like leniency or strictness.

[22] examined the shift toward electronic administration in government institutions in Libya to meet the challenges of the digital age. The study used descriptive analytical approach and the field study method. To achieve the study objectives, a research methodology allowing for the collection of secondary data via literature review was used, and for primary data questionnaires were used during a fieldwork exercise.

[9] studied the relationship of strategy execution plan dimensions on organization performance of higher educational institution in Palestine. The findings revealed that strategy execution plan dimensions significantly affect organizational performance as hypothesized and suggest that the higher education in Palestine can be enhanced through an effective strategy execution.

[14] examined strategy execution by Thai large companies for ASEAN economic community and indicated that though senior officials believed strategic execution leads to better performance most of them do not have the said strategies.

\section{RESEARCH METHODOLOGY}

The study adopted a descriptive research design. The target population for the study was 4230 employees within the senior management cadre in 132 specific government state agencies. Purposive sampling was used to sample 365 respondents. The study administered questionnaires containing open ended and closed ended questions to all respondents via drop and pick approach. Data was analyzed using descriptive and inferential statistics. The inferential statistics was conducted by ANOVA, regression, Bcoefficient and correlation analysis. The regression model for this study was:

$$
\mathrm{Y}=\alpha_{0}+\beta_{1} \mathrm{X}_{1}+\varepsilon
$$

The model for the moderating effect was as follows; where $\mathrm{X}$ is the predictor and $\mathrm{Z}$ is the hypothesized moderator.

$$
\mathrm{Y}=\mathrm{a}+\mathrm{B}_{1} \mathrm{X} \times \mathrm{Z}+\mathrm{e}
$$




\section{RESEARCH FINDINGS}

\section{A. Response Rate}

The study had a sample of 365 respondents who were surveyed using a structured questionnaire. A response rate of $81.6 \%$ (298 respondents) was achieved and the data used for analysis.

\section{1) E-Administration}

Findings imply that E-Administration was a key strategy of E-Government adoption by the state agencies. Through use of E-Administration, it was clear that communication was enhanced as well as properly coordinated information sharing and service delivery. The findings concur with [10] who found that E-Government was mainly enhanced by EAdministration whereby the state departments and agencies adopt electronic based communication and instructional procedures to deliver their mandate. As contended by [11], if an organization intent to achieve the value for its resources, using E-Administration strategies such as IFMIS would be the way to go. These findings also reap support from [18] who upholds the need for technological innovations in both public and private administration through which accountability, efficiency and proper management is achieved.

$H_{o l}$ : E-Administration has no significant influence on service delivery by the state agencies in Kenya

The study sought to find out the statistical relationship between E-Administration and service delivery by the state agencies in Kenya. The statistical relationship between the two variables was sought through regression model whereby the output was generated in terms of model summary, ANOVA and regression coefficients. The findings on the model summary revealed that the $\mathrm{R}^{2}$ for the model was 0.615 an indication E-Administration accounts for up to $61.5 \%$ variation of public service delivery among the state agencies in Kenya.

TABLE I: MODEL SUMMARY FOR E-ADMINISTRATION

\begin{tabular}{ccccc}
\hline Model & $\mathrm{R}$ & R Square & $\begin{array}{c}\text { Adjusted R } \\
\text { Square }\end{array}$ & $\begin{array}{c}\text { Std. Error } \\
\text { of the } \\
\text { Estimate }\end{array}$ \\
\hline 1 & $0.784^{\mathrm{a}}$ & 0.615 & 0.614 & 0.7715 \\
\hline
\end{tabular}

Predictors: (Constant), Electronic Administration

Analysis of Variance (ANOVA) consists of calculations that provide information about levels of variability within a regression model and form a basis for tests of significance. The " $F$ " column provides a statistic for testing the hypothesis that all $\beta \neq 0$ against the null hypothesis that $\beta=0$ [25].

The ANOVA results revealed that at an F-calculated of 446.069 and significant at a significant level of $0.000<0.05$. This implies that the service delivery among state agencies in Kenya could be explained by E-Administration and that the model was significant to give a direction on whether to reject or fail to reject the null hypothesis.

\begin{tabular}{ccccccc}
\multicolumn{6}{c}{ TABLE II: ANOVA (ANALYSIS OF VARIANCE) FOR E-ADMINISTRATION } \\
\hline \multirow{2}{*}{ Model } & $\begin{array}{c}\text { Sum of } \\
\text { Squares }\end{array}$ & df & Mean Square & F & Sig. \\
\hline \multirow{2}{*}{1} & Regression & 265.539 & 1 & 265.539 & 446.069 & $0.0000^{\mathrm{a}}$ \\
& Residual & 166.085 & 296 & 0.8023 & & \\
& Total & 431.624 & 297 & & & \\
\hline
\end{tabular}

a. Predictors: (Constant), E-Administration

b. Dependent Variable: Service Delivery.
The regression coefficients shown in Table III on the other hand revealed that at a beta coefficient of 0.572 , EAdministration significantly and positively influenced service delivery by the state agencies in Kenya at a significance level of 0.000 . The model now becomes:

$$
\mathrm{Y}=5.739+0.572 \mathrm{X}_{3}+e
$$

This implies that a unit change in E-Administration leads to $57.2 \%$ increase in service delivery by the state agencies in Kenya. This therefore gives a go-ahead to reject the null hypothesis of the study that E-Administration has no significant influence on service delivery by the state agencies in Kenya.

TABLE III: COEFFICIENT RESULTS FOR E-ADMINISTRATION

\begin{tabular}{|c|c|c|c|c|c|}
\hline & \multicolumn{2}{|c|}{$\begin{array}{c}\text { Unstandardized } \\
\text { Coefficients }\end{array}$} & \multirow{2}{*}{$\begin{array}{c}\begin{array}{c}\text { Standardized } \\
\text { Coefficients }\end{array} \\
\text { Beta }\end{array}$} & \multirow{2}{*}{$\mathrm{t}$} & \multirow{2}{*}{ Sig. } \\
\hline & $\mathrm{B}$ & $\begin{array}{c}\text { Std. } \\
\text { Error }\end{array}$ & & & \\
\hline (Constant) & 5.739 & 0.687 & & 8.354 & 0.0000 \\
\hline E-Administration $\left[\mathrm{X}_{3}\right]$ & 0.572 & 0.253 & 0.519 & 2.261 & 0.000 \\
\hline
\end{tabular}

a. Dependent Variable: Service Delivery.

\section{2) Moderating effect of Strategy Execution}

The moderating influence of strategy execution on the relationship between E-Administration and public service delivery was established in the study.

Strategy execution process stands to steer the success of every strategy that an organization puts in place. Through effective means of executing a given strategy, the organization is able to streamline its operations towards the strategy and reap employees support on the same. The findings however show that strategy execution has not been effectively done in the state agencies surveyed. [9] contemplate that coming up with strategy is one thing and seeing the successful execution of the strategy is another.

The findings showed that strategy execution was recognized as a key aspect in steering adoption of EGovernment strategies, but it was not properly done by the surveyed state agencies. The findings gain support from the contingency theory of management that upholds the need for strategy execution for strategic decisions to be successful through proper strategy formulation, situational analysis, strategy implementation and evaluation [26].

According to the results of the overall model, EAdministration had a significant and positive effect on performance of state corporations when moderated by strategy execution although the significance was lower.

\section{TABLE IV: REGRESSION COEFFICIENTS FOR THE MODERATED MODEL}

\begin{tabular}{|c|c|c|c|c|c|}
\hline \multirow[t]{2}{*}{ Model } & & \multicolumn{2}{|c|}{$\begin{array}{c}\text { Unstandardized } \\
\text { Coefficients }\end{array}$} & \multirow{2}{*}{$\begin{array}{c}\begin{array}{c}\text { Standardized } \\
\text { Coefficients }\end{array} \\
\text { Beta }\end{array}$} & \multirow[t]{2}{*}{ Sig. } \\
\hline & & B & Std. Error & & \\
\hline \multirow[t]{2}{*}{1} & (Constant) & 2.57 & 0.267 & & 0.000 \\
\hline & E-A & -0.284 & 0.034 & -0.437 & 0.000 \\
\hline \multirow[t]{3}{*}{2} & (Constant) & 1.479 & 0.38 & & 0.000 \\
\hline & E-A & -0.229 & 0.035 & -0.352 & 0.000 \\
\hline & S-E & 0.25 & 0.065 & 0.229 & 0.000 \\
\hline \multirow[t]{4}{*}{3} & (Constant) & 3.247 & 0.615 & & 0.000 \\
\hline & E-A & -0.312 & 0.036 & -0.48 & 0.000 \\
\hline & S-E & -0.122 & 0.125 & -0.112 & 0.331 \\
\hline & & 0.041 & 0.007 & 0.376 & 0.000 \\
\hline
\end{tabular}

a Dependent Variable: S-Delivery. 


\section{CONCLUSION}

The study sought to assess the influence of EAdministration on public service delivery by the state agencies in Kenya. The findings showed that most of the state agencies surveyed had adopted the major E-Administration aspects which include Electronic data interchange platforms, Integrated human resource and payroll systems, integrated financial management systems and Web-based collaborative platforms. The study concluded that E-Administration played a significant role in promoting delivery of public services by the state agencies in Kenya. Through adoption of Integrated Data Interchange and Integrated Human Resource and Payroll Systems, the management of the employees as well as access of customer data was enhanced thus streamlining service delivery to the citizens. The adoption of Integrated Financial Management Systems (IFMIS) enhanced accountability and effective use of public resources thus reducing wastage and achieving value for money among the agencies.

\section{RECOMMENDATIONS}

E-Administration is an important step towards enabling running of the state agencies. The agencies through their management should therefore ensure that E-Administration is adopted through embrace of different aspects such as the Integrated Human Resource and Payroll Systems and Integrated Financial Management Systems. Through these systems, the agencies are able to achieve accountability and integrity in dealing with public funds as well as effectively managing the workforce to ensure productivity and commitment to service delivery. The management of state agencies could enhance the use of strategy execution practices so as to enable success of E-Administration strategies which are significant to enhanced public service delivery.

\section{REFERENCES}

[1] Adegbola, E. A. (2018). Strategic Marketing Practices and Environmental Perception of Customer Oriented Service in Nigeria Deposit Money Banks in Lagos State. European Scientific Journal, ESJ, 14(28), 292.

[2] Ahmadi Zeleti, F., Ojo, A., \& Uusitalo, O. (2013, October). Entrepreneurism and e-government in Finland: barriers to entry. In Proceedings of the 7th International Conference on Theory and Practice of Electronic Governance (pp. 124-133). ACM.

[3] Wallang, M. (2018). Determinants that Influence Citizen's Usage of Different E-Government Services: A Malaysian Case Study.

[4] Khan, M. (2013). E-government, GIS and good governance. Public management, 95(1), 18-23.

[5] World Bank (2012) World Development Report, New York: Oxford University Press.

[6] Lavanya, D. (2015). A study on impact of ERP based e governance in Chennai corporation.

[7] Simões, M. J. (2011). Sociological Reflections on E-government. In ICDS 2012: The Sixth International Conference on Digital Society (pp. 29-34). International Academy, Research, and Industry Association (IARIA).

[8] Mungai, A. N. (2017). E-government strategy implementation and performance of the public sector in Kenya. International Academic Journal of Human Resource and Business Administration, 2(3), 301338.

[9] Siam, M., \& Hilman, H. (2014). Relationship of Strategy Execution Plan Dimensions on Organization Performance of Higher Educational Institution in Palestine. Asian Social Science, 10(13), 131.
[10] Irawan, B., Sumartono, Wijaya, A. F., \& Nurfitriyah (2014). Implementation of E-Government in Public Service. A Study in Population and Civil Recording Agency in Samarinda Municipality. Public Policy and Administration Research 4(6), 112-122.

[11] Lucianelli, G., \& Citro, F. (2017). Financial conditions and financial sustainability in higher education: a literature review. In Financial Sustainability in Public Administration (pp. 23-53). Palgrave Macmillan, Cham.

[12] Atkin, D. J., Hunt, D. S., \& Lin, C. A. (2015). Diffusion theory in the new media environment: Toward an integrated technology adoption model. Mass Communication and Society, 18(5), 623-650.

[13] Kiende, C. K., Mukulu, E.\& Odhiambo, R. (2019). Influence of Strategic Innovation on the Performance of Small and Medium Women-Owned Enterprises in Kenya, Journal of Entrepreneurship \& Project Management, 3(1), 50-67.

[14] Ali, E., Younas, M., \& Saeed, T. (2016) Impact of Moderating Role of e-Administration on Training, Performance Appraisal and Organizational Performance. World Academy of Science, Engineering and Technology, International Journal of Social, Behavioural, Educational, Economic, Business and Industrial Engineering, 10(11), 3764-3770.

[15] Litondo, K. O. \& Ntale, J. F. (2013). Determinants of mobile phone usage for e-commerce among micro and small enterprises in the informal sector of Kenya. International Journal of Applied Science and Technology, 3(6), 16-23.

[16] Alshehri, M., \& Drew, S. (2010). Challenges of eGovernment Service Adoption in Saudi Arabia from eReady Citizen Perspective: World Academy of Science, Engineering and Technology. Volume 66. Pages 1053- 1059 .

[17] Nam, T. (2018). Examining the anti-corruption effect of e-government and the moderating effect of national culture: A cross-country study. Government Information Quarterly, 35(2), 273-282.

[18] Rogers, E. M. (2010), Diffusion of Innovations (4th ed.), New York, NY: Simon and Schuster.

[19] Jameel, A., Asif, M., \& Hussain, A. (2019). Good Governance and Public Trust: Assessing the Mediating Effect of E-Government in Pakistan. Lex Localis, 17(2), 299-320.

[20] Monauni, M. (2017) "Closing the strategy execution gap through business simulations", Development and Learning in Organizations: An International Journal, Vol. 31 Issue: 4, pp.912, https://doi.org/10.1108/DLO-08-2016-0069.

[21] Wirtz, J., \& Lovelock, C. (2016). Services Marketing: People, Technology, Strategy $\left(8^{\text {th }}\right.$ ed.). World Scientific Publishing Company.

[22] Allen, B. A., Julliet, L., Paquet, G., \& Roy, J. (2011). E-governance and Government online in Canada: partnerships, people and prospects. Government information Quarterly 18(2),93-104.

[23] Krishnan, A. (2016). Implementation of quality initiatives in Indian public and private sector organizations: a comparative analysis. International Journal of Quality \& Reliability Management, 33(2), 246-266.

[24] Yigit E.O., and Colak K. (2010), The opinions of the pre-service teachers about e-democracy in Turkey, Procedia - Social and Behavioral Sciences, 2(2), 712-716.

[25] Roy, D. (2015). Understanding the Delhi urban waterscape through the actor network theory. Public Works Management \& Policy, 20(4), 322-336.

[26] Tosi Jr, H. L., \& Slocum Jr, J. W. (1984). Contingency theory: Some suggested directions. Journal of management, 10(1), 9-26.

[27] Teece, D., \& Pisano, G. (2003). The dynamic capabilities of firms. In Handbook on knowledge management (pp. 195-213). Springer, Berlin, Heidelberg.

[28] United Nations (2014). Global EGovernment Readiness Report 2008 from E-Government to EInclusion. [Online], United Nations Division for Public Administration and Development Management, http://unpan1.un.org/intradoc/groups/public/documents/un /unpan028607.pdf.

[29] United Nations (2014). UN EGovernment Survey 2010, [Online], Retrieved

http://unpan1.un.org/intradoc/groups/public/documents/un /unpan038851.pdf.

[30] United Nations (2012). Global EGovernment Readiness Report 2005 from E-Government to EInclusion. [Online], United Nations Division for Public Administration and Development Management, Retrieved from, http://unpan1.un.org/intradoc/groups/public/documents/un /unpan021888.pdf. 
European Journal of Business and Management Research www.ejbmr.org

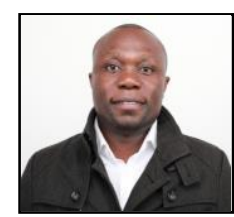

Riany, K. G. is $\mathrm{PhD}$ finalist at the Jomo Kenyatta University of Agriculture and Technology (Kenya) pursuing a g Doctor of Philosophy in Strategic Management. He holds a Master of Science in Strategic Management of ICT and a Bachelors' degree in Computer Science. 